\title{
Hubungan kondisi lingkungan keluarga dengan hasil belajar siswa sekolah menengah atas
}

\author{
Nofitria Eka Putri ${ }^{1}$, Herman Nirwana ${ }^{2}$, Syahniar $^{3}$ \\ ${ }^{123}$ Universitas Negeri Padang
}

Article Info:

Accepted 19 Desember 2018

Published Online 07 Januari 2019

\begin{abstract}
Hasil belajar merupakan gambaran kemampuan siswa setelah mengikuti proses belajar mengajar dalam rentangan waktu tertentu. Belajar itu sendiri merupakan suatu proses dari seseorang yang berusaha untuk memperoleh suatu bentuk perubahan perilaku yang relatif menetap. Salah satu faktor yang diduga mempengaruhi adalah kondisi lingkungan keluarga. Penelitian ini bertujuan untuk: (1) untuk mendeskripsikan hasil belajar siswa, (2) untuk mendeskripsikan kondisi lingkungan keluarga, dan (3) untuk menguji hubungan antara kondisi lingkungan keluarga dengan hasil belajar siswa. Penelitian ini menggunakan metode kuantitatif dengan jenis pendekatan deskriptif dan korelasional. Populasi penelitian ini adalah 180 siswa. Instrument yang digunakan adalah kuisioner Kondisi Lingkungan Keluarga. Data dianalisis dengan teknik statistik deskriptif dan teknik Pearson Product Moment. Temuan penelitian ini mengenai kondisi lingkungan keluarga siswa berada pada kategori sedang dan hasil belajar siswa berada pada kategori sedang dan juga terdapat hubungan positif yang signifikan antara kondisi lingkungan keluarga dengan hasil belajar siswa dengan koefisien korelasi 0,219 dengan taraf signifikan 0,000. Penelitian ini sangat penting agar kondisi lingkungan keluarga dapat diminimalkan lagi dengan hasil belajar siswa.
\end{abstract}

Keyword: kondisi lingkungan keluarga, hasil belajar siswa

This is an open access article distributed under the Creative Commons Attribution License, which permits unrestricted use,
distribution, and reproduction in any medium, provided the original work is properly cited. C2018 by author

\section{PENDAHULUAN}

Bimbingan dan konseling (BK) sebagai bagian integral dari pelayanan pendidikan merupakan upaya pelayanan bantuan untuk peserta didik baik secara perorangan maupun secara kelompok. Pendidikan merupakan usaha sadar untuk mempersiapkan peserta didik mengembangkan potensinya melalui proses pembelajaran yang tersedia pada jalur, jenjang, dan jenis pendidikan tertentu untuk masa depannya. Dalam undang-undang sistem pendidikan nasional nomor 20 tahun 2003, pasal 1 tentang sistem pendidikan nasional menyatakan bahwa: pendidikan adalah usaha sadar dan terencana untuk mewujudkan suasana belajar dan proses pembelajaran agar peserta didik secara aktif mengembangkan potensi dirinya untuk memiliki kekuatan spiritual keagamaan, pengendalian diri, kepribadian, kecerdasan, akhlak mulia, dan keterampilan yang diperlukan dirinya, masyarakat, bangsa dan negara. Berdasarkan penjelasan di atas jelaslah bahwa pelaksanaan pendidikan yang dilakukan oleh pendidik di sekolah dapat membantu dan mengembangkan segala potensi yang dimiliki oleh siswa tersebut. Pelayanan bimbingan dan konseling telah memiliki pola yang jelas sebagaimana dikemukakan Prayitno (2009:2-3) yang meliputi delapan bidang bimbingan, sepuluh jenis layanan, dan enam jenis kegiatan pendukung. Salah satu bidang bimbingan adalah bidang bimbingan belajar. Salah satu indikator keberhasilan suatu pendidikan dapat dilihat dari hasil belajar siswa. Menurut Suryabrata (2004: 320) hasil belajar adalah hasil yang diperoleh siswa yang dapat dilihat melalui angka atau lambang pada rapor sebagai perumusan terakhir hasil belajar. Secara idealnya sebuah kegiatan belajar dapat dikatakan efisien apabila dengan usaha belajar tertentu dapat menghasilkan hasil belajar yang tinggi dari proses belajarnya (Syah, 2005: 144). Menurut Prayitno (1997: 2) hasil belajar yang ideal adalah apabila siswa mampu menguasai sepenuhnya (90-100\%) segenap materi pelajaran dengan berbagai tuntutan yang meliputi unsur-unsur ranah kognitif, afektif dan psikomotor. Hasil belajar sangat berperan penting dalam meningkatkan mutu pembelajaran siswa untuk 
mengembangkan wawasan dan pengembangan skill yang dimiliki siswa melalui proses pembelajaran agar terwujudnya hasil belajar siswa yang diharapkan. Berdasarkan penelitian yang dilakukan Citra (2014) hasil belajar siswa SMAN 1 Kota Solok pada umumnya berada pada kategori rendah dengan persentase dan tidak ada yang berada pada kategori sangat rendah sedangkan Fauzan (2015) juga menjelaskan perolehan hasil belajar siswa SMA 2 Depok berada pada kategori sedang dengan persentase sebesar tiga puluh tiga persen. Menurut Netral (2011) SMA 1 Sungai Penuh terdapat siswa yang memiliki hasil belajar tinggi sebanyak 40 siswa dengan persentase empat puluh tuju persen sedangkan untuk persentase hasil belajar yang rendah dari 47 siswa lima puluh dua persen. Menurut Arjoni (2013) hasil belajar siswa SMAN 7 Padang diketahui dengan kategori sedang persentasenya empat puluh persen dan kategori rendah tiga puluh persen. Dari beberapa penelitian di atas dapat diambil kesimpulan bahwasannya hasil belajar siswa masih rendah. Hasil belajar juga dipengaruhi oleh beberapa faktor, baik yang berasal dari dalam individu maupun dari luar diri individu itu sendiri.

Menurut Fernanda (2012) hasil belajar adalah segala perilaku yang dimiliki oleh siswa akibat proses belajar yang ditempuh meliputi semua aspek akibat proses belajar yang berlangsung di sekolah atau luar sekolah, bersifat kognitif, afektif, dan psikomotor baik disengaja ataupun tidak. Perilaku hasil belajar merupakan kecakapan nyata yang terkait dengan standar kesempurnaan.

Dari beberapa hasil penelitian di atas, maka dapat disimpulkan bahwa hasil belajar siswa masih dalam kategori yang rendah. Melihat fenomena tersebut maka peneliti merasa perlu mengkaji lebih dalam berkaitan dengan kedua variabel yang telah peneliti uraikan. Sehingga nantinya melalui hasil penelitian ini, peneliti dapat membantu memberikan gambaran yang jelas mengenai hasil belajar dan kondisi lingkungan belajar siswa kepada pihak-pihak terkait seperti guru, konselor dan kepala sekolah, agar pihak-pihak terkait tersebut mampu memberikan bantuan dan membentuk kebijakan yang positif untuk merubahnya.

Menurut Slameto (2003: 54) dalam hasil belajar adanya faktor internal seperti: (a) kesehatan mental, (b) cacat tubuh, (c) konsentrasi belajar, (d) mengolah bahan ajar, (e) rasa percaya diri, (f) intelegensi dan kesulitan belajar. Selanjutnya faktor eksternalnya seperti: (a) keluarga, (b) sarana prasarana pembelajaran, (c) kebiasaan penilaian, (d) lingkungan masyarakat. Di dalam lingkungan sosial itu terdapat lingkungan keluarga.

\section{METODE}

Jenis penelitian ini merupakan penelitian kuantitatif dengan dengan jenis deskriptif korelasional yang bertujuan untuk mendeskripsikan kondisi lingkungan keluarga (X) dan hasil belajar siswa (Y). Populasi penelitian ini siswa kelas X, dan XI SMAN 4 Kota Solok yang berjumlah 315 orang dan sampel sebanyak 180 siswa yang dipilih dengan Stratified Random Sampling dan juga Proposional Random Sampling Instrumen yang digunakan adalah Kuesioner Kondisi Lingkungan Keluarga dan Ledger Nilai Siswa. Data yang dikumpulkan dianalisis menggunakan statistik desktiptif dan teknik Pearson Product Moment.

\section{HASIL DAN PEMBAHASAN}

Berdasarkan pengolahan data yang telah dilakukan, maka data hasil penelitian disajikan dan dianalisis sesuai dengan tujuan penelitian yang diajukan sebelumnya, yaitu (1) mendeskripsikan hasil belajar siswa, (2) mendeskripsikan kondisi lingkungan keluarga dan (3) menguji hubungan kondisi lingkungan keluarga dengan hasil belajar siswa.

\section{Hasil Belajar Siswa}

Secara keseluruhan hasil belajar siswa SMA N 4 Kota Solok berada pada kategori tinggi sedang $84,44 \%$. Temuan penelitian dapat dipaparkan sebagai berikut.

Tabel 1. Hasil Belajar Siswa

\begin{tabular}{lccrr}
\hline KATEGORI & \multicolumn{2}{c}{ SKOR } & F & \% \\
\hline Sangat Tinggi & $\geq \mathrm{M}+1.5 \mathrm{SD}$ & $\geq 90$ & 0 & 0.00 \\
Tinggi & $\mathrm{M}+0.5 \mathrm{SD}$ s/d $<\mathrm{M}+1.5 \mathrm{SD}$ & $\geq 83-<90$ & 19 & 10.56 \\
Sedang & $\mathrm{M}-0.5 \mathrm{SD}$ s/d $<\mathrm{M}+0.5 \mathrm{SD}$ & $\geq 75-<83$ & 152 & 84.44 \\
Rendah & $\mathrm{M}-1.5 \mathrm{SD}$ s/d $<\mathrm{M}-0.5 \mathrm{SD}$ & $\geq 68-<75$ & 2 & 1.11 \\
Sangat Rendah & $<\mathrm{M}-1.5 \mathrm{SD}$ & $<68$ & 7 & 3.89 \\
\hline
\end{tabular}

Tidak ada siswa yang memiliki kondisi hasil belajar dalam kategori sangat tinggi, $10.56 \%$ tinggi, $84.44 \%$ sedang, $1.11 \%$ rendah, dan $3.89 \%$ berada pada kategori sangat rendah. Berkenaan dengan kemampuan yang 
diperoleh sebagai hasil belajar Bloom (dalam Nana Sudjana, 2004: 22) membagi hasil belajar dalam tiga ranah yaitu: ranah kognitif, ranah efektif, dan ranah psikomotor, di sekolah ranah kognitif dapat dilihat pada pengetahuan yang diterima anak setelah guru memberikan materi pembelajaran di kelas. Ranah afektif ditampilkan melalui kehadiran anak di kelas juga menentukan nilai yang diperolehnya dalam setiap bidang studi pelajaran. Ranah psikomotor juga dapat dilihat dari tugas-tugas yang dikerjakan dan keakrifan siswa dalam mengikuti proses pembelajaran di kelas.

Menurut Wira (2013) Siswa yang tekun dalam belajar akan meraih hasil yang baik, karena siswa yang tekun dalam belajar biasanya tidak mudah putus asa sehingga akan terus-menerus belajar dalam situasi yang sulitpun. Siswa yang memiliki ketekunan dalam belajar akan selalu berusaha untuk hadir di kelas dan mengikuti proses belajar dengan penuh perhatian. Menurut Wulandari (2013) agar persentase hasil belajar siswa selalu meningkat, upaya dari dalam diri maupun dari luar diri siswa. Upaya dari dalam diri siswa dapat berupa meningkatkan keterampilan-keterampilan belajar yang siswa miliki dan mengulang kembali pelajaran di rumah dan mengerjakan tugas yang diberikan oleh guru di sekolah sehingga siswa mendapatkan hasil belajar yang optimal.

\section{Kondisi Lingkungan keluarga}

Hasil penelitian menunjukan bahwa pada umumnya kondisi lingkungan keluarga berada pada kategori sedang sebesar 76,17\%. Temuan penelitian dapat dipaparkan sebagai berikut.

Tabel 2. Kondisi Lingkungan Keluarga

\begin{tabular}{|c|c|c|c|c|c|c|c|c|c|c|c|c|c|c|}
\hline \multirow{3}{*}{ No } & \multirow{3}{*}{ Sub Variabel } & \multicolumn{10}{|c|}{ Klasifikasi } & \multirow{2}{*}{\multicolumn{3}{|c|}{ RATA-RATA }} \\
\hline & & \multicolumn{2}{|c|}{ ST } & \multicolumn{2}{|c|}{$\mathbf{T}$} & \multicolumn{2}{|c|}{$\mathbf{S}$} & \multicolumn{2}{|c|}{$\mathbf{R}$} & \multicolumn{2}{|c|}{ SR } & & & \\
\hline & & $\mathbf{F}$ & $\%$ & $\mathbf{F}$ & $\%$ & $\mathbf{F}$ & $\%$ & $\mathbf{F}$ & $\%$ & $\mathbf{F}$ & $\%$ & Skor & $\%$ & Kat \\
\hline 1 & $\begin{array}{l}\text { Cara Orangtua } \\
\text { Mendidik }\end{array}$ & 16 & 9 & 76 & 42,2 & 71 & 39,44 & 17 & 9,44 & 0 & 0 & 20,61 & 68,72 & sedang \\
\hline 2 & $\begin{array}{l}\text { Relasi antar } \\
\text { Anggota Keluarga }\end{array}$ & 17 & 9,44 & 81 & 45 & 67 & 37,22 & 15 & 8,33 & 0 & 0 & 20,91 & 69,70 & sedang \\
\hline 3 & Suasana Rumah & 51 & 28,33 & 57 & 31,67 & 60 & 33,33 & 12 & 6,67 & 0 & 0 & 13,88 & 69,42 & sedang \\
\hline 4 & $\begin{array}{l}\text { Keadaan } \\
\text { Ekonomi } \\
\text { Keluarga }\end{array}$ & 15 & 8,33 & 69 & 38,33 & 76 & 42,22 & 0 & 0 & 11,11 & 11,1 & 20,33 & 67,78 & sedang \\
\hline $\mathbf{J u}$ & nlah kseseluruhan & 4 & 2,25 & 62 & 34,83 & 112 & 62,92 & 2 & 1,12 & 0 & & 76,17 & 69,24 & sedang \\
\hline
\end{tabular}

Berdasarkan hasil analisis data yang dilakukan terungkap bahwa secara keseluruhan kondisi lingkungan keluarga berada pada kategori sedang sebesar 76,17\%. Temuan penelitian ini ditunjang oleh pendapat Menurut Slameto (2003:63) Suasana rumah dimaksudkan sebagai situasi atau kejadian yang sering terjadi di dalam keluarga dimana anak berada dan melakukan berbagai aktivitasnya, termasuk belajar. Pentingnya pendidikan anak di lingkungan keluarga menjadikan keluarga mempunyai pengaruh positif terhadap keberhasilan anak dalam hasil belajarnya. Cara orangtua mendidik, relasi antar anggota keluarga, pengertian dan perhatian orangtua, latar belakang kebudayaan juga akan mempengaruhi hasil belajar siswa. Dalam meningkatkan hasil belajar yang baik juga diperlukan kerja sama antara pihak sekolah dengan orangtua siswa.

Menurut Mori (2015) Dukungan sosial orangtua yang termasuk pada tingkat pencapaian cukup ini perlu ditingkatkan lagi karenadengan dukungan sosial orangtua yang lebih baik maka kemampuan siswa dalam melakukan aktivitas dalam belajar akan semakin baik.

\section{Hubungan Kemampuan Mengelola Emosi dengan Kecenderungan Berperilaku Agresif Siswa}

Selanjutnya dilakukan uji hipotesis. Hipotesis yang diajukan dalam penelitian ini terdapat hubungan yang positif yang signifikan antara kondisi lingkungan keluarga dengan hasil belajar siswa.

Tabel 3. Hubungan Kondisi Lingkungan Keluarga (X) dengan Hasil Belajar Siswa (Y)

\begin{tabular}{lllll}
\hline Aspek & $\mathbf{N}$ & Rhitung & Sig & Kesimpulan \\
\hline $\mathbf{X}$ & 180 & 0,219 & 0,000 & Berkorelasi \\
$\mathbf{Y}$ & & & & \\
\hline
\end{tabular}

Berdasarkan tabel 3 tersebut dapat dilihat koefisien korelasi antara kondisi lingkungan keluarga dengan hasil belajar siswa sebesar 0,219 dan taraf signifikan 0,00. Hubungan yang signifikan positif ini dapat diartikan, semakin tinggi kondisi lingkungan keluarga maka hasil belajar siswa juga tinggi. Sebaliknya, semakin rendah kondisi lingkungan keluarga makin rendah pula hasil belajar siswa. Hal tersebut membuktikan bahwa hipotesis 
yang meganyatakan adanya korelasi antara kondisi lingkungan keluarga dengan hasil belajar siswa di SMAN 4 Kota Solok dapat diterima.

Penelitian ini dilakukan untuk mengetahui ada tidaknya hubungan antara kondisi lingkungan keluarga dengan hasil belajar siswa di SMAN 4 Kota Solok, menggunakan rumus Pearson Correlation, hasil yang diperoleh dari pengajuan hipotesis mengungkapkan bahwa terdapat hubungan signifikan antara kondisi lingkungan keluarga dengan hasil belajar siswa di SMAN 4 Kota Solok. Dari hasil analisis dengan menggunakan Product Moment Correlation memperlihatkan koefisien korelasi 0,219 dengan taraf signifikan 0,00 dengan jumlah responden 180 siswa. Jika dibandingkan dengan probilitasnya 0,05 maka $0,045<0,05$ oleh karena itu hipotesis kerja (Ha) yang diajukan dalam penelitian adalah terdapat hubungan yang signifikan antara kondisi lingkungan keluarga dengan hasil belajar siswa dapat diterima. Sehingga dapat ditafsirkan bahwa terdapat hubungan yang signifikan antara kondisi lingkungan keluarga dengan hasil belajar siswa. Sedangkan untuk (Ho) diterima karena hasil korelasi positif antara kondisi lingkungan keluarga denga hasil belajar siswa.

Menurut Sukmadinata (Hidayati, 2015:2) Keluarga merupakan lingkungan pertama dan utama dalam pendidikan, memberikan landasan dasar bagi proses belajar bagi pihak sekolah dan masyarakat. Di dalam hasil belajar faktor lingkungan sangat berpengaruh sekali terhadap hasil belajar siswa. Lingkungan keluarga yang sangat banyak mempengaruhi kegiatan belajar adalah orang tua dan keluarga siswa itu sendiri. Keluarga merupakan tempat siswa melakukan sosialisasi untuk pertama kalinya dan merupakan lingkungan pertama dalam pembentukan kepribadian dan kemampuan anak. Dalam membantu anak meningkatkan hasil belajar siswa, orangtua harus dapat menciptakan suasana rumah yang nyaman untuk belajar. Menurut Slameto (2003:63) Suasana rumah dimaksudkan sebagai situasi atau kejadian yang sering terjadi di dalam keluarga dimana anak berada dan melakukan berbagai aktivitasnya, termasuk belajar. Dari uraian tersebut dapat disimpulkan bahwa lingkungan keluarga erat kaitannya dengan hasil belajar siswa.

\section{KESIMPULAN}

Berdasarkan hasil penelitian dan menguji hipotesis mengenai korelasi kondisi lingkungan keluarga dengan hasil belajar siswa, dapat disimpulkan sebagai berikut: (1) Secara umum kondisi lingkungan keluarga siswa di SMAN 4 Kota Solok berada pada kategori sedang, artinya sebagian besar siswa SMAN 4 Kota Solok sudah memenuhi bagaimana cara orangtua mendidik, relasi dengan antar keluarga. (2) Secara umum kondisi hasil belajar siswa SMAN 4 Kota Solok dikategorikan sedang, artinya hasil belajar siswa SMAN 4 Kota Solok sudah cukup baik dan masih ditingkatkan lagi yang lebih baik. (3) Terdapat hubungan positif yang signifikan antara kondisi lingkungan keluarga dengan hasil belajar siswa. Artinya siswa yang memiliki kondisi lingkungan keluarga tinggi maka hasil belajar juga tinggi, sebaliknya jika kondisi lingkungan keluarganya rendah maka hasil belajarnya juga rendah. Sedangkan hasil yang diperoleh oleh peneliti kondisi lingkungan keluarga di SMAN 4 Kota Solok sedang untuk hasil belajar siswanya juga berada pada kategori sedang.

\section{DAFTAR RUJUKAN}

Citra. (2014). Hubungan Interaksi sosial dengan hasil belajar Siswa SMAN 1 Kota Solok. Skripsi.Tidak diterbitkan. Padang: BK FIP UNP.

Cristal. W. Afrizal Sano \& Yusri. (2013). Hubungan Keterampilan Mencatat dengan Hasil Belajar Siswa. Jurnal Ilmiah Konseling. Volume 2 nomor 1, 83-87.

Dianto, M, Nurhizrah \& Mudjiran. (2015). Kontribusi Dukungan Sosial dan Konsep Diri terhadap Motivasi Berprestasi Siswa di SMP Negeri Kecamatan Batang Kapas Pesisir Selatan. Jurnal Konselor. Volume 4 Nomor 1, 19-25.

Fernanda, M. M. Afrizal Sano \& Nurfanah. (2012). Hubungan Antara Kemampuan Berinteraksi Sosial dengan Hasil Belajar Siswa. Jurnal Ilmiah Konseling. Volume 1 Nomor 1, 1-7.

Hanum, M, Prayitno \& Herman Nirwana. (2015). Efektifitas Layanan Konseling Perorangan MeningkatkanKemandirian Siswa dalam Menyelesaikan Masalah Belajar. Jurnal Konselor. Volume 4 Nomor 3, 162-168.

Prayitno. (1997). Dasar-Dasar Bimbingan dan Konseling. Jakarta: Rineka Cipta.

Prayitno. (2009). Dasar Teori dan Dasar Pendidikan. Padang: Grasindo.

Slameto. (2003). Belajar dan Faktor - faktor yang Mempengaruhinya. Jakarta: Rineka Cipta

Suryabrata, S. (2004). Bimbingan dan Pembelajaran. Jakarta: Rineka Cipta.

Sudjana, N. (2009). Penilaian Hasil \& Proses Belajar Mengajar. Jakarta: Rineka Cipta.

Syah, M. (2004). Psikologi Belajar. Jakarta: PT. Raja Grafindo.

Sukmadinata, N.S. (2003). Landasan Psikologi Proses Pendidikan. Bandung:Remaja Roesdakarya.

Tahira, A. (2013). Pengaruh Lingkungan Sosial Terhadap Hasil Belajar Pada Mata Pelajaran Ekonomi (Survey Pada Siswa Kelas X SMA Pasundan Kota Bandung). Skripsi. tidak diterbitkan. Bandung: UPI Bandung. 
Undang-undang Republik Indonesia No. 20 Tahun 2003. Tentang Sistem Pendidikan Nasional. Jakarta: Sinar Grafika.

Solina, W, Erlamsyah \& Syahniar. (2013). Hubungan Antara Perlakuan Orangtua dengan Motivasi Belajar Siswa di Sekolah. Jurnal Ilmiah Konseling. Volume 2 Nomor 1, 289-294. 